\title{
DEREK FRANK RENN CBE PhD FIA FSS FSoCAntiquaries
}

\section{0-2019}

One of Derek's many contributions to the profession was to edit the Journal of the Institute of Actuaries, one of the predecessor journals of the BAJ, from 1970 to 1980. In recognition of this, his obituary is reproduced below. It was first published in The Actuary magazine in July 2019.

EDITOR BAJ

Derek Renn was born in Hackney on 16 February 1930, the only son of Frank Edward Renn and Dorothy Elizabeth (née Girling). He won a scholarship to Queen Elizabeth's Grammar School, Barnet, in 1941. Although conditions were not propitious for taking up a place offered to him at Merton College, Oxford, he was successful in the Civil Service open executive competition in 1948. In Derek's own words, he was serendipitously allocated to the Government Actuary's Department, where he served for 44 years, retiring in 1992 as senior actuary and establishment officer (head of HR in today's terms). He was made a CBE in the 1992 Birthday Honours.

Derek spent his national service as an officer in the RAF (1956-1958) and then qualified as an actuary in 1959. He served the profession as an Actuarial Tuition Service tutor in demography, friendly societies, life interests and reversions, and subsequently as an assistant editor and then the editor of the Journal of the Institute of Actuaries (JIA) from 1970 to 1980 . He was the author and co-author of several papers in JIA and in the Journal of the Institute of Actuaries Students' Society. He regularly contributed notes to JIA on articles, papers and publications of actuarial interest. He also spent periods on the Education Committee, the Library Committee, the Sessional Meetings Committee and the Medals and Prizes Committee of the Institute of Actuaries. He was the editor of Life, Death and Money, a book made up of contributions from a number of actuaries to celebrate the 150th anniversary of the Institute of Actuaries in 1998. His counsel was often sought regarding the purchase by the library of books for the historical collection.

Derek had a lifelong interest in archaeology and particularly in Norman castles, which started with a calligraphically handwritten essay on castles that was awarded second place in his school's Librarian's Prize in 1947. He won the British Archaeological Association's Taylor Prize in 1959 for his article on "the Anglo-Norman keep". His magnum opus, Norman Castles in Britain, was published in 1968 and remained in print for 20 years. He also wrote a considerable number of papers (more than 130) for the Antiquaries Journal, Medieval Archaeology and numerous other archaeological journals, as well as several official guides to British castles, such as Pevensey, Kenilworth and Caerphilly. In 2001, he was awarded the Society Medal of the Society of Antiquaries of London, having served on its council from 1972 to 1973 and as its treasurer in the 1990s. He completed his $\mathrm{PhD}$ - on the development of fortification in England from 1166 to 1216 - with the University of Southampton in 1978.

Derek was a committee member of the Civil Service Insurance Society (CSIS) from 1982 to 2015 and served as a trustee of the related CSIS Charity Fund from 2007 to 2010, following

\footnotetext{
(c) Institute and Faculty of Actuaries 2019. This is an Open Access article, distributed under the terms of the Creative Commons Attribution licence (https://creativecommons.org/licenses/by/4.0/), which permits unrestricted re-use, distribution, and reproduction in any medium, provided the original work is properly cited.
} 
the separation of the Society and Charity governance structures in 2007. He was a Freeman of the City of London and a liveryman of the Worshipful Company of Actuaries.

Derek was a charming and courteous gentleman, unassuming but highly knowledgeable in his areas of expertise, maintaining throughout his life a strong interest in all matters historical. He will be remembered by many in different contexts as a delightful colleague. He passed away on 31 May 2019, aged 89 and is fondly remembered by his widow Margaret Ann and by a son and daughter.

Chris Daykin CB MA FIA FSA FSS

Cite this article: Daykin C. DEREK FRANK RENN CBE PhD FIA FSS FSoCAntiquaries 1930-2019. British Actuarial Journal. 